\title{
Some Aspects of Urea Metabolism in North American Bison
}

\author{
Edward O. KEITH, James E. ELLIS, Robert W. PHILLIPS, \\ Melvin I. DYER \& Gerald M. WARD
}

\begin{abstract}
Keith E. O., Ellis, J. E., Phillips R. W., Dyer M. I. \& Ward G. M., 1981: Some aspects of urea metabolism in North American bison. Acta theriol., 26, 14: 257-268 [With 1 Table \& 5 Figs.].

Previous studies comparing the digestive capacity of bison (Bison bison) with that of cattle (Bos taurus) indicated that bison may digest low-quality forage to a greater extent than cattle. In an attempt to determine the relationship between digestive ability and whole animal nitrogen budget, we measured urea concentrations in the blood, in the saliva, in the urine, and in the rumen of two groups of bison; one fed a high-protein diet, the other fed a low-protein diet. We found differences between groups in urea levels in some body pools but not in others. Results suggest that urea metabolism in bison responds to dietary N-levels, but further research is needed to clarify this response.

[Natural Resource Ecol. Lab., Colorado State Univ., Fort Collins, Co. 80523, USA].
\end{abstract}

\section{INTRODUCTION}

The American bison is a native of prairies and grasslands and presumably well adapted to the forages available in these ecosystems. In a comparative study of the diets of cattle and bison, Peden et al. (1974) found that bison consumed diets composed of a higher proportion of grasses (92-99\% dry matter) than did cattle in the same pasture (70- $86 \%$ dry matter). Likewise, cattle diets were higher in forbs and shrubs $(14-30 \%$ dry matter) than those of bison ( $1-8 \%$ dry matter). Peden et al. (197 $\left.\varepsilon_{s}\right)$ also found that bison diets were lower in digestibility, higher in crude fiber and lower in crude protein than the diets of cattle in the same pasture. However, using the nylon bag technique, Peden et al. (1974) discovered that forage placed in the rumen of bison was digested to a significantly greater extent than the same forage placed in the rumen of cattle. This held true for bison diets, for cattle diets, and for a standard grass hay.

Extending this study, Hawley et al. (1977) determined Dry Matter Digestibility $(D M D)$ values (again using the nylon bag technique with both 
bison and cattle) for forages collected from the Great Slave River lowlands in Canada (an important bison winter range). They found the $D M D$ values to be consistently higher for bison than for cattle for all forages tested.

Elsewhere, Gębczyńska et al. (1974) compared apparent digestion coefficients for a variety of nutrients between European bison and cattle. They found digestion coefficients for crude protein and ether extract to be higher in bison than in cattle, but coefficients for cellulose, soluble carbohydrates, and readily hydrolyzable carbohydrate were higher for cattle than bison.

These apparent differences in digestive powers of bison and cattle were hypothesized by Peden (1972) to be related to urea metabolism and recycling. Hypothetically, bison are adapted to major seasonal changes in forage quality, including very low protein content winter forages, and are capable of recycling urea from body pools into the rumen under conditions of low forage protein. This recycled urea would presumably assist in maintaining a favorable rumen environment for microbial protein synthesis and activity and thus would result in greater forage digestion than if the microbes were dependent on the forage protein alone. Cattle, (hypothetically) being selected for production efficiency, respond better to high quality diets but are less efficient at urea recycling on low-protein diets than bison.

Urea-supplied as a diet-additive is known to increase the digestibility of low-quality high-fiber diets (Loosli \& McDonald, 1968). In the rumen, urea is hydrolized to ammonia and can be used for protein synthesis by rumen microorganisms. But urea is also a product of protein digestion and of protein catabolism and so is a normal component of the blood. Urea may also enter the rumen by diffusion from the blood (Houpt, 1959; Cocimano \& Leng, 1967). Rate of urea diffusion from blood to rumen is dependent upon concentration gradients and positively correlated with high blood urea nitrogen $(B U N)$ levels and with low ruminal ammonia concentrations (Ford \& Milligan, 1969; Varady et al., 1967).

Urea also enters the rumen in saliva (McDonald, 1962; Somers, 1961 a, $b, c, d)$. The mechanism of urea transfer from blood to saliva is apparently passive diffusion, as the saliva urea concentration is proportional to BUN (Packett \& Groves, 1967; Bailey \& Balch, 1961). Salivary urea concentrations are also directly correlated to ruminal ammonia levels (Lewis, 1957).

Waldo (1968) suggested that transfer of urea from blood to rumen is four to six times greater than the transfer to the rumen of salivary urea, while Houpt (1959) found blood-rumen transfer to be 16 times greater than salivary transfer. Thornton (1970) has disputed Houpt's results, but 
it is evident that direct transfer across the rumen wall is quantitatively greater than salivary transfer (Wales, 1972), although salivary urea transfer is undoubtedly an important pathway for urea and other nitrogen transfer into the rumen (Somers, 1961d).

It seems plausible that low forage-protein in the diet would result in low ruminal ammonia values which in turn might lead to greater movement of urea from the blood and saliva back into the rumen than when forage protein and resulting ruminal ammonia values are higher. However, other work suggests that these interactions are not simple. Somers (1961b) found correlations between nitrogen (N) intake, salivary $\mathrm{N}$, and urinary $\mathrm{N}$. Although $B U N$ was not correlated to $\mathrm{N}$ intake, BUN and salivary urea concentrations were highly correlated $(r=0.96)$. Lewis (1957) found that BUN was better correlated to ruminal ammonia concentration than to $\mathrm{N}$ intake, although Torrel et al. (1974) found significant correlations between $\mathrm{N}$ intake and $B U N(r=0.99)$. On high- $\mathrm{N}$ diets where ruminal ammonia concentrations are high, Lewis (1957) found the greatest variation in $B U N$.

\section{MATERIALS AND METHODS}

A preliminary experiment was carried out to determine baseline nitrogen levels in various body pools of bison, fed on both low- and high-N diets. Six animals were used in this experiment. They were maintained at the Pawnee Site, the field research facility of the Natural Resources Ecology Laboratory, Colorado State University, located on the USDA/AR Central Plains Experimental Range near Nunn, Colorado (Jameson, 1969).

Table 1

Diet groups of bison.

\begin{tabular}{llll}
\hline Treatment & Sex & Fistula type & Fistulation date \\
\hline Group A-High-N diet & & & \\
Bison 10 & $\mathbb{M}^{1}$ & $\mathrm{R}^{2}$ & 16 September 1975 \\
Bison 12 & $\mathrm{F}$ & $\mathrm{R}$ & 12 December 1975 \\
Bison 15 & $\mathrm{F}$ & $\mathrm{E}$ & 1971 \\
Group B-Low-N diet & $\mathrm{M}$ & $\mathrm{E}$ & 1971 \\
Bison 1 & $\mathrm{F}$ & $\mathrm{R}$ & 1971 \\
Bison 8 & $\mathrm{F}$ & $\mathrm{R}$ & 12 December 1975 \\
Bison 13 & & \\
\hline
\end{tabular}

${ }^{1} \mathrm{~F}=$ female, $\mathrm{M}=$ male, ${ }^{2} \mathrm{E}=$ esophageal, $\mathrm{R}-$ ruminal.

The bison used in this experiment were originally obtained from the Wichita Mountain Wildlife Refuge in Oklahoma as calves in 1969 and 1970 and were five and six years old at the start of this experiment. The bison were divided into two groups of 3 animals. The animal number, sex, fistula type, fistulation date, and experimental treatment are shown in Table 1. Group A (high-N) was fed a diet of crested wheatgrass hay ( $6 \%$ crude protein, $4030 \mathrm{cal} / \mathrm{g}$ gross energy) and 
a pelleted supplement $(15 \%$ crude protein, $4160 \mathrm{cal} / \mathrm{g}$ gross energy). Group B (iow-N) received a ration of the hay only ad libitum. Both groups received water ad libitum. Unfortunately we could not monitor food intake on an individual basis. Therefore, the food (and nitrogen) intake values used here are mean values (per animal) based on the total intake of each group.

All animals were weighed each week and sampled for $\mathrm{N}$-content of blood, rumen fluids, saliva, and urine. Each group was kept in small holding pastures, which contained little forage, and rotated between pastures each week. Samples were taken in alternating fashion, with blood from one group and urine from the other being taken each week, and reversing the next. Saliva and ruminal fluids were taken from fistulated animals each week, and saliva was taken from animals without esophageal fistulae before they were bled, every other week. The trial lasted for 17 weeks, from 11 November 1975 until 9 March 1976.

Blood was taken from the external jugular vein by venous puncture. Generally, $8 \mathrm{ml}$ of blood were taken, mixed with thrichloroacetic acid (TCA) $(100 \mathrm{mg} T C A / \mathrm{ml}$ blood), and centrifuged (2000 rpm for $10-20 \mathrm{~min}$.). The plasma was then decanted into a snap-cap vial, and frozen for later analysis.

Sampling of ruminal fluids from animals fistulated 12 December began on 16 December, sampling from all other animals with rumen fistulae began 11 November. A portable, hand actuated vacuum pump was used to draw rumen fluids into a $250-\mathrm{ml}$ flask through a section of rigid tubing. Ruminal fluids were taken from several sites within the rumen to insure a representative sample. From 50 to $200 \mathrm{ml}$ of fluids were taken, and a composite sample of $50 \mathrm{ml}$ was filtered through cheesecloth into two vials. To prevent loss of ammonia, the filtrate was acidified with concentrated sulphuric acid to a pH of 1-2 (Giesecke \& Van Gylswyk, 1975). After acidification the samples were labeled and frozen. The procedure for implantation of the small diameter rumen cannulae, as well as the methods employed in their manufacture, were described by Rupp \& Keith (1976).

It was not possible to collect urine continuously for 24 hours. For this reason, and because the urinary concentration varies with water intake, it was necessary to relate the urinary-urea concentration to a constituent in the urine that does not vary with water intake and urine production. The excretion of creatinine is constant over successive 24-hour periods, being dependent on the muscle mass of the animal (Ganong, 1975). Creatinine can also be used as an index to glomerular filtration rate, which does not vary under normal conditions. Therefore, the quantity of urea in a urine sample was compared to the amount of creatinine in the same sample. In this way, it was possible to make comparisons among animals and within the same animal over time.

Samples were analyzed for urea content by a modification of the method of Foster \& Hockholzer (1971). Analysis of urine for creatinine followed a modification of the method of Hare (1950) and Owen et al. (1954). Ruminal ammonia was analyzed with an ammonia-selective electrode after liberation of ammonia by the addition of excess sodium hydroxide.

Because it was not possible to compare a given $B U N$ value with its corresponding urine urea concentration, as these samples were taken on alternate weeks; and because we could not monitor on an individual animal basis, it was assumed that a given sample from either diet group was representative of that group, and no attempt was made to differentiate between animals in either group or between sample dates except as indicated. The results are presented on a monthly vasis and values are treatment group means. To develop the regression equations 
between $B U N$, salivary urea, and ruminal ammonia concentrations, the values for the two vials of ruminal fluids from each sample date from each animal were averaged, giving one value from which to derive regression equations by the method of least squares. Data from each group were compared using an unpaired Student's $t$ test.

\section{RESULTS AND DISCUSSION}

The bison receiving the high-protein diet consumed an average of $25.56 \mathrm{~kg}$ of hay per week. This amounts to $0.25 \mathrm{~kg} \mathrm{~N}$ ingested per animal per week ( 0.97 percent $\mathrm{N}$ in the hay). These animals also consumed an average of $26.72 \mathrm{~kg}$ of supplement per week, which at 2.42 percent $\mathrm{N}$ by weight contributed $0.65 \mathrm{~kg} \mathrm{~N}$ per animal per week. These animals weighed an average of $432 \mathrm{~kg}$ during the trial, thus the total $\mathrm{N}$ intake of $0.9 \mathrm{~kg}$ per animal per week was about 0.2 percent of body weight ingested per week ( 0.03 percent body weight per day).

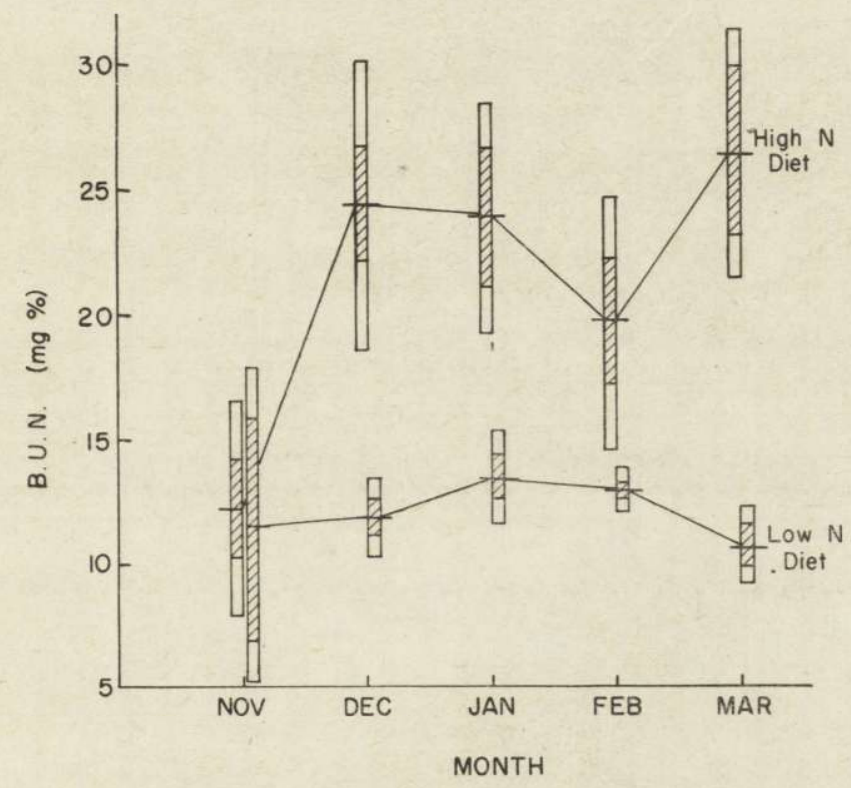

Fig. 1. Blood urea nitrogen concentration averaged over months. (Solid bar: Standard Error, Open bar: Standard Deviation).

Bison receiving the low-protein diet consumed an average of 51.93 $\mathrm{kg}$ of hay per week for an average $\mathrm{N}$ intake of $0.5 \mathrm{~kg}$ per animal per week. These bison weighed an average of $489 \mathrm{~kg}$ during the trial, and thus their $\mathrm{N}$ intake was about 0.1 percent of body weight per week ( 0.015 percent body weight per day), or about one-half the amount consumed by the high- $\mathrm{N}$ group. The $\mathrm{N}$ intakes of the groups were significantly different $(P<0.001)$. 
Bison receiving the high- $\mathrm{N}$ diet maintained their body weights throughout the trial, and were beginning to gain weight at the end of the trial. The bison on the low- $\mathrm{N}$ diet lost weight slowly during the trial and weighed significantly less $(P<0.001)$ at the end of the trial than they did at the beginning.

The bison on the high-N diet had significantly higher $(P<0.001) B U N$ values than the bison on the low- $\mathrm{N}$ diet. Monthly averages of $B U N$ values for both groups are shown in Fig. 1. The high-N animals had average $B U N$ values of $20.63 \mathrm{mg} / \mathrm{dl}$ during the trials, while the animals on the low- $\mathrm{N}$ diet had average $B U N$ values of 12.33 . These values compare well with those of Kirkpatrick et al. (1975), who found that white-tailed deer (Odocoileus virginianus) fawns receiving a high- $N$ diet had $B U N$ values of $23.6 \mathrm{mg} / \mathrm{dl}$, while fawns receiving a low-N diet had $B U N$ values of 11.0. These authors suggested that a two-fold increase in $\mathrm{N}$ intake could result in a two-fold increase in BUN.

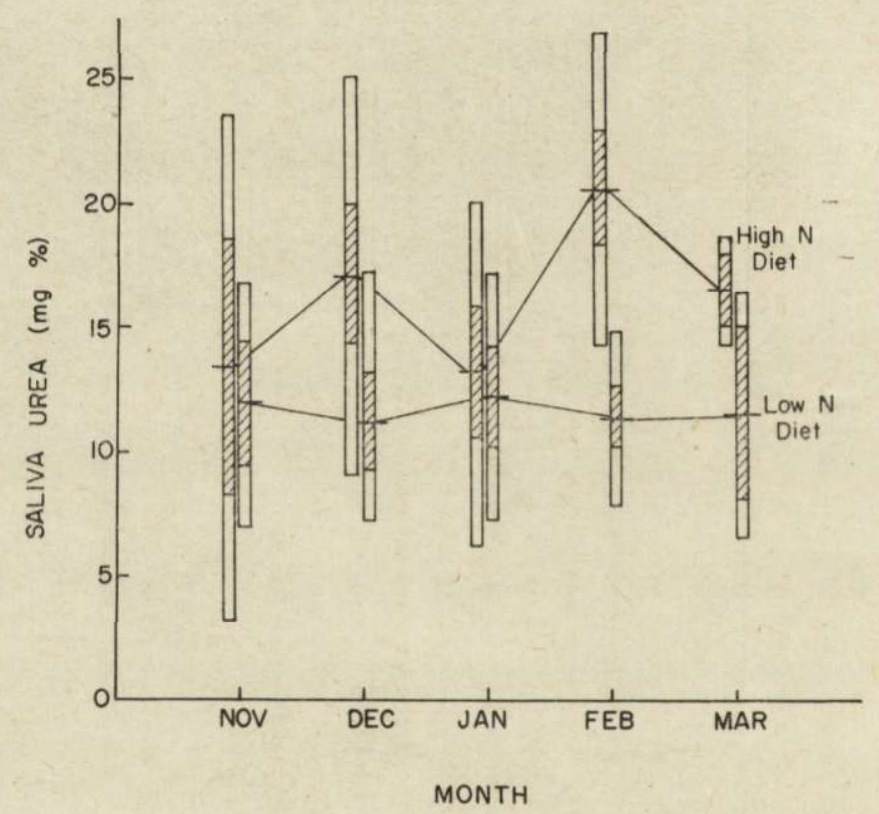

Fig. 2. Salivary urea concentration averaged over months. (Solid bar: Standard Error, Open bar: Standard Deviation).

Blood urea nitrogen can increase due to the catabolism of tissue protein, urea being produced in the urea cycle following deamination for gluconeogenesis (Leibholz, 1970). This may help the ruminant meet its immediate energy needs, and it may help the animal maintain its ruminal microflora by increasing total urea recycled (Robbins et al., 1974). It is possible that the low- $\mathrm{N}$ diet group catabolized body fat stores for 
maintenance energy during the trial; however, we found no ewidence of protein catabolism either as a source for energy or nitrogen for recycling, as $B U N$ was low.

The bison receiving the high- $\mathrm{N}$ diet had significantly higher $(P<0.01)$ salivary urea concentrations than did the bison on the low-N diet. Fig. 2 shows a monthly comparison of salivary urea levels between the diet groups of bison. As Somers (1961b) found, salivary urea concentrations were never greater than $B U N$.

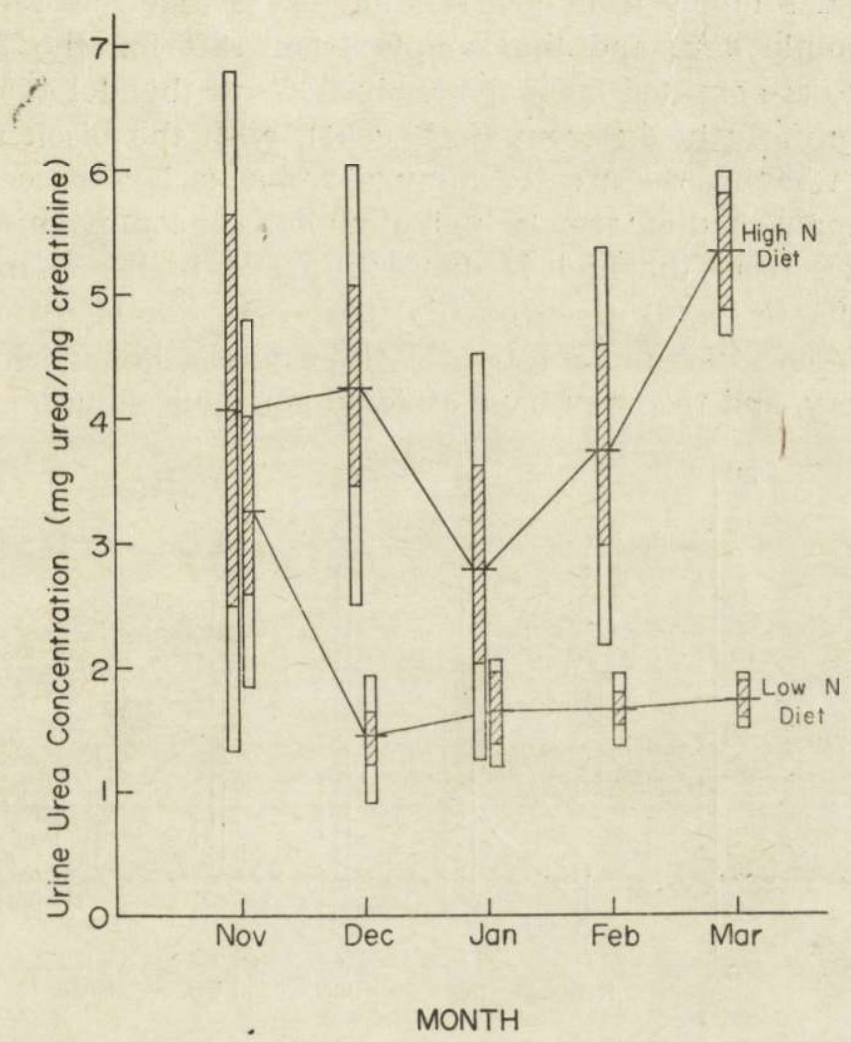

Fig. 3. Urine urea concentration (expressed as $\mathrm{mg}$ urea per $\mathrm{mg}$ creatinine) averaged over months. (Solid bar: Standard Error, Open bar: Standard Deviation).

Urinary urea concentrations, when expressed as mg urea excreted per mg creatinine excreted, were also significantly higher $(P<0.001)$ for the bison on the high-N diet than for the bison on the low-N diet, as shown in Fig. 3. Both Robbins et al. (1974) and Kirkpatrick et al. (1975) found that deer could change the renal clearance of urea in order to maintain an "optimum" or normal BUN level. Deer fed high-N diets had BUN values which decreased during their trials, while deer on low-N diets 
had $B U N$ values which increased, with $B U N$ levels in both groups approaching the "optimum" value. In contrast, we found no significant changes in BUN in either group of bison. Both groups maintained their respective $B U N$ levels through the 17 -week trial. This might suggest that urea conservation in bison, if it occurs, depends neither on changing the clearance of urea in the kidney, as in deer, nor on an active transport mechanism in the kidney.

Ruminal ammonia concentrations were not different $(P<0.05)$, unless rumen fluid samples from low- $\mathrm{N}$ animals $8 \mathrm{~B}$ and $13 \mathrm{~B}$ for the 18 December sample date and the sample from 13B for the 23 December sample date are omitted from the analysis. With this deletion, the groups become significantly different $(P<0.0001)$, with the bison receiving the high-N diet having the greater ruminal ammonia levels (see Fig. 4). The deleted samples had extremely high ammonia concentrations, higher than any samples from the high-N diet group and higher than the normal range of $10-45 \mathrm{mg} / \mathrm{dl}$ given by Church (1974). Samples from 13B were the first taken after implantation of the cannula, being taken one week after surgery, and this may have affected ammonia values.

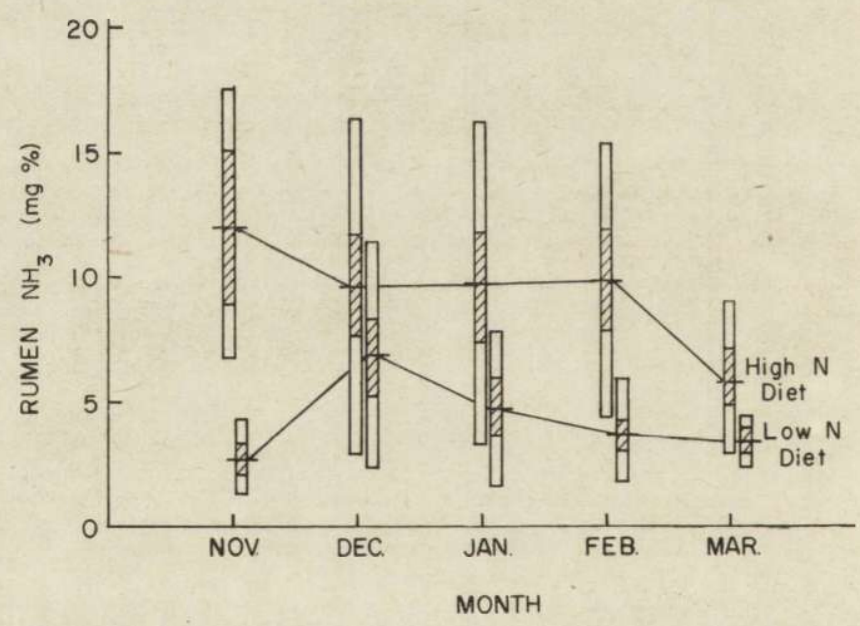

Fig. 4. Ruminal amniunia concentration averaged over months. (Solid bar: Standard Error, Open bar: Standard Deviation).

Lewis (1957) found that 30 sheep consuming a grass diet had average ruminal ammonia concentrations of $44.9 \mathrm{mg} / \mathrm{dl}$, while two sheep fed an unspecified type of hay for $20 \mathrm{~d}$ had ruminal ammonia levels of 36.9 $\mathrm{mg} / \mathrm{dl}$. IIume et al. (1970) reported that sheep had average ruminal ammonia concentrations of $6.3 \mathrm{mg} / \mathrm{dl}$ when fed a low-N diet $(2.65 \mathrm{~g} / \mathrm{d} \mathrm{N})$ and $30.7 \mathrm{mg} / \mathrm{dl}$ when fed a high-N diet $(15.95 \mathrm{~g} / \mathrm{d} \mathrm{N})$. Ruminal ammonia 
levels in the bison were lower than these. Giesecke \& Van Gylswyk - (1975) found that African grazers had lower ruminal ammonia levels than African browsers and that grazers had large rumen capacities as well. Rumen samples from three grazing species: African buffalo (Synceros caffer), blue wildebeeste (Connochaetes taurinus), and gemsbok (Oryx gazella) had average ruminal ammonia concentrations of 7.2, 2.8, and $6.1 \mathrm{mg} / \mathrm{dl}$, respectively. The ruminal ammonia values from the bison are close to these, especially for the bison on the low- $\mathrm{N}$ diet.

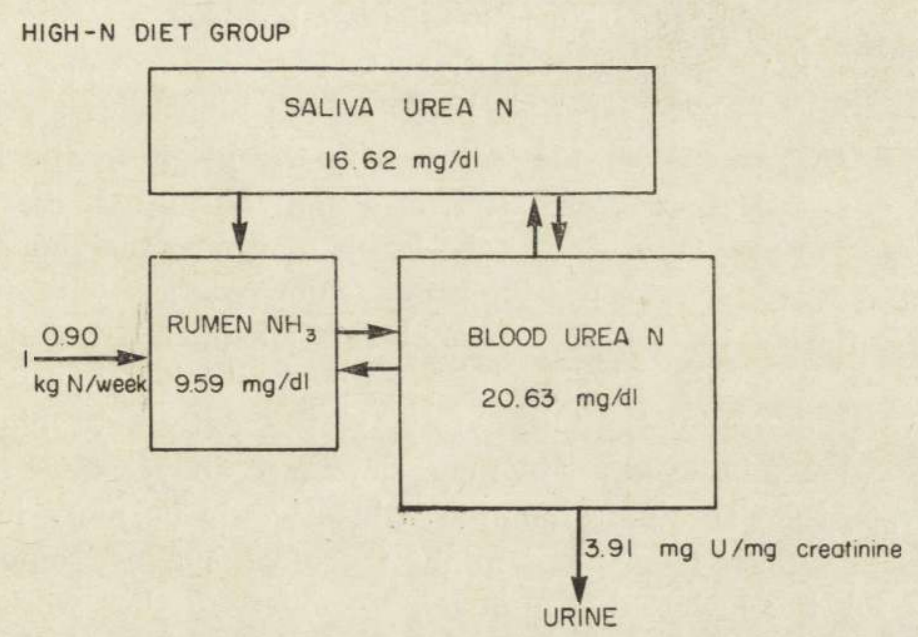

LOW-N DIET GROUP

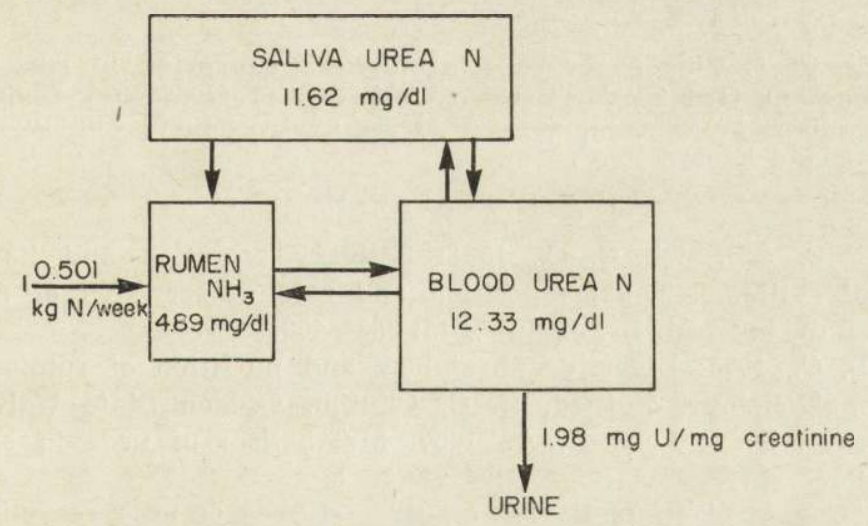

Fig. 5. Schematic diagram showing comparisons of all parameters for each group of bison. Values are averaged for the entire trial.

Regression equations describing the relationship of $B U N$ to salivary urea concentrations and to ruminal ammonia concentrations were derived from pooled data from both groups. Both regressions are significant $(P<$ $<0.01)$. 
Salivary urea $(\mathrm{mg} / \mathrm{dl})=2.93+0.71 \times B U N(\mathrm{mg} / \mathrm{dl})\left(R^{2}=0.40\right)$

Rumen ammonia $(\mathrm{mg} / \mathrm{dl})=-0.93+0.57 \times B U N(\mathrm{mg} / \mathrm{dl})\left(R^{2}=0.40\right)$

An analysis of covariance indicated that $B U N$ influenced both ruminal ammonia and salivary urea concentrations. However, this analysis indicated that other unknown factors had a greater controlling influence than BUN (see also Somers, 1961b).

If data from both groups of bison are averaged over the 17-week trial, some interesting relationships are suggested (Fig. 5). Bison receiving approximately one-half as much $\mathrm{N}$ in their diet excreted about one-half as much urea in their urine, and had ruminal ammonia concentrations approximately one-half as large as bison in the high-N diet group. However, the $B U N$ and salivary urea levels in the bison on the low-N diet were not one-half the values of the bison on the high- $\mathrm{N}$ diet, but were only reduced to about two-thirds the levels of bison receiving the high-N diet. If urea transport is a passive process, depending solely on diffusion, greater similarity to the proportional relationships between $\mathrm{N}$ intake, $\mathrm{N}$ excretion, and ruminal ammonia levels would be expected in BUN and salivary urea levels. Alternately, if the extremely high ruminal ammonia values observed on two occasions (see above) were included in the analysis, then ruminal ammonia values would be more in line with the saliva and $B U N$ levels, and might therefore suggest some urea conservation for the low- $\mathrm{N}$ diet animals. However, further work is needed to clarify the relationships among these body pools and the processes determining pool size.

Acknowledgement: This paper reports on work supported in part by National Science Foundation Grant BMS73-02027 A04 to the Grassland Biome, U.S. International Biological Program, for "Analysis of Structure, Function, and Utilization of Grassland Ecosystems".

\section{REFERENCES}

1. Bailey C. B. \& Balch C. C., 1961: Salivary secretion and its relation to feeding of cattle. 2. The composition and rate of secretion of mixed saliva in the cow during rest. Br. J. Nutr., 15: 383-402.

2. Church D. C., 1975: Digestive physiology and nutrition of ruminants. Vol. 1. Digestive physiology. 2nd ed. D. C. Church. Oregon State Univ., Corvallis.

3. Cocimano M. R. \& Leng R. A., 1967: Metabolism of urea in sheep. Br. J. Nutr., 21: 353-371.

4. Ford A. L. \& Milligan L. P., 1969: Tracer studies of urea recycling in sheep. Can. J. Anim. Sci., 50: 129-135.

5. Foster R. B. \& Hockholzer J. M., 1971: A single-reagent manual method for directly determining urea nitrogen in serum. Clin. Chem., 17: 921-925.

6. Ganong W. F., 1981: Review of medical physiology. Lange Medical Publications, Inc., Los Altos. CA.

7. Gębczyńska Z., Kowalczyk J., Krasińska M., \& Ziołecka A., 1974: A comparison of the digestibility of nutrients by European bison and cattle. Acta theriol., 19: 282-289. 
8. Giesecke D. \& Van Gylswyk N. O., 1975: A study of feeding types and certain rumen functions in six species of South African wild ruminants. J. Agric. Sci. (Camb.), 85: 75-83.

9. Hare R. S., 1950: Endogenous creatinine in serum and urine. Proc. Soc. Exp. Biol. Med., 74: 148-151.

10. Hawley A. W. L., Peden D. G., Reynolds H. W. \& Keith E., 1977: Nylon bag digestibilities of five native plants in bison and cattle. Can. J. Anim. Sci. 57: 825 .

11. Houpt T. R., 1959: Utilization of blood urea in ruminants. Am. J. Physiol., 197: $115-120$.

12. Hume I. D., Moir R. J. \& Somers M., 1970: Synthesis of microbial protein in rumen. I. Influence of the level of nitrogen intake. Aust. J. Agric. Res., 21: 283-296.

13. Jameson D. A., 1969: General description of the Pawnee Site. US/IBP Grassland Biome Tech. Rep. No. 1. Colorado State Univ., Fort Collins. 32 p.

14. Kirkpatrick R. L., Buckland D. E., Abler W. A., Scanlon P. F., Whelan J. B. \& Burkhart H. E., 1975: Energy and protein influences on blood urea nitrogen of white-tailed deer fawns. J. Wildl. Manage., 39: 692-698.

15. Leibholz J., 1970: The effect of starvation and low nitrogen intakes on the concentration of free amino acids in the blood plasma and on the nitrogen metabolism in sheep. Aust. J. Agric. Res., 21: 723-734.

16. Lewis D., 1957: Blood-urea concentration in relation to protein utilization in the ruminant. J. Agric. Sci. (Camb.), 48: 438-446.

17. Loosli J. K. \& McDonald I. W., 1968: Nonprotein nitrogen in the nutrition of ruminants. FAO Agric. Study No. 75. FAO, Rome.

18. McDonald I. W., 1952: The role of ammonia in ruminal digestion of protein. Biochem. J., 51: $86-90$.

19. Nolan J. V., Norton B. W. \& Leng R. A., 1976: Further studies of the dynamics of nitrogen metabolism in sheep. Br. J. Nutr., 35: 127-147.

20. Owen J. A., Iggo B., Scandrett F. J. \& Stewart C. P., 1954: The determination of creatinine in plasma or serum, and in urine: a critical examination. Biochem. J., 58: 426-437.

21. Packett L. V. \& Groves T. D. D., 1965: Urea recycling in the ovine. J. Anim. Sci., 24: $341-346$.

22. Peden D. G., 1972: The trophic relations of Bison bison to the shortgrass prairie. Ph. D. Thesis. Colo. State Univ., Ft. Collins, Colo.

23. Peden D. G., Van Dyne G. M., Rice R. W. \& Hansen R. M., 1974: The trophic ecology of Bison bison (L.) on shortgrass plains. J. Appl. Ecol. 11: $489-498$.

24. Robbins G. T., Prior R. L., Moen A. N. \& Visek W. J., 1974: Nitrogen metabolism of white-tailed deer. J. Anim. Sci., 38: 186-191.

25. Rupp G. P. \& Keith E. O,, 1976: Rumen fistulae in bison. \{In: "Todays research-Tomorrows Colorado", Proc. 89th Ann. Res. Conf. Colo. State Univ., Fort Collins, Colo.]

26. Somers M., 1961a: Factors influencing the secretion of nitrogen in sheep saliva. 1. The distribution of nitrogen in the mixed and parotid saliva of sheep. Aust. J. Exp. Biol., 39: 111-122.

27. Somers M., 1961b: Factors influencing the secretion of nitrogen in sheep saliva. 2. The influence of nitrogen intake on blood urea nitrogen and upon the total nitrogen and urea nitrogen in the parotid saliva of sheep. Aust. J, Exp. Biol., 39: 123-132. 
28. Somers M., 1961c: Factors influencing the secretion of nitrogen in sheep saliva. 3. Factors affecting the nitrogen fractions in the parotid saliva of sheep with special reference to the influence of ammonia production in the rumen and fluctuations in level of blood urea. Aust. J. Exp. Biol., 5: $133-144$.

29. Somers M., 1961d: Factors influencing the secretion of nitrogen in sheep saliva. 4. The influence of injected urea on the quantitative recovery of urea in the parotid saliva and the urinary excretions of sheep. Aust. J. Exp. Biol., 39: 145-156.

30. Thornton R. F., 1970: Factors effecting the urinary excretion of urea nitrogen in cattle. II. The plasma urea nitrogen concentration. Aust. J. Agric. Res., 21: $145-152$.

31. Torrell D. T., Hume I. D. \& Weir W. C., 1974: Factors affecting blood urea nitrogen and its use as and index of the nutritional status of sheep. J. Anin. Sci., 39: 435-440.

32. Varady J., Boda K., Havassy I., Bajo M. \& Thomas J., 1967: The relationship between urea retention to ammonia concentration in the rumen of sheep after intravenous administration of urea. Physiol. Bohemoslov., 16: $571-555$.

33. Waldo D. R., 1968: Symposium: Nitrogen utilization in the ruminant. Nitrogen metabolism by the ruminant. J. Diary Sci., 51: 265-275.

34. Wales R. A., 1972: Comparisons of urea recycling in caribou, cattle, ard sheep. Ms. Thesis. Univ. Alberta, Edmonton.

Accepted, November 10, 1980.

Edward O. KEITH, James E. ELLIS, Robert W. PHILLIPS, Melvin I. DYER i Gerald M. WARD

\section{METABOLIZM MOCZNIKA U BISON BISON}

\section{Streszczenie}

Dotychczasowe badania porównawcze nad strawnością u bizona (Bison bisor) i bydła (Bos taurus) wskazują, że bizon może trawić pokarm gorszej jakości w stopniu znacznie wyższym niż bydło. Aby wyjaśnić to zagadnienie, autorzy zajdi się bilansem i obiegiem azotu w organizmie bizonów. Do badań użyto 6 dorosłyłh bizonów ( 2 byki i 4 krowy) podzielonych na dwie grupy żywieniowe: o niskin i wysokim poziomie azotu w dawkach pokarmowych. Spożycie pasz, a w nih azotu, określano średnio dla grupy. Doświadczenie trwało 17 tygodni w okrese jesienno-zimowym. Badano poziom mocznika w krwi (Ryc. 1), ślinie (Ryc. 2), mczu (Ryc. 3) i amoniaku w żwaczu (Ryc. 4). Zarówno poziom mocznika w krvi, ślinie i moczu, jak i amoniaku w żwaczu był dodatnio skorelowany $\mathrm{z}$ poziomen azotu w paszy. Im więcej bizony otrzymywały azotu w paszy, tym więcej w:dalały mocznika w moczu. Jedynie ilość $\mathrm{N}$ w ślinie i krwi bizonów karmionyh paszą niskobiałkową była nieco wyższa niż połowa wartości tych wskaźników u bizonów trzymanych na paszy wysokobiałkowej. 